\title{
Implementasi FMADM Untuk Mendukung Keputusan Pemilihan Jenis Lampu Di Laboratorium Teknologi Informasi Politeknik Negeri Padang
}

\author{
Fitroi Nova
}

\begin{abstract}
Abstrac - Lighting installation is very necessary in designing a building. The amount oflight intensity on each room is different depending on the us ability of the room it self. Simple Additive weighting (SAW) method could be used in selecting the right lamp. The greater the value of alternative earn edit the better alternative. Based on this SAW method, it is advisable touse lights that are LED with the highest on value of 9.66 , then the TL lamps with a criteria on value of 6.93 .
\end{abstract}

\section{Keywords:Cost, Lamp,Benefit, Lighting, SAW}

Abstrak - Instalasi penerangan merupakan hal yang sangat dibutuhkan dalam merancang sebuah bangunan. Besarnya intensitas cahaya pada setiap ruangan berbeda tergantung dari kegunaan dari ruangan itu sendiri. Metode Simple Additive Weighting (SAW) bisa dipergunakan dalam pemilihan lampu yang tepat. Semakin besar nilai alternatif yang diperoleh maka semakin baik alternatif itu. Berdasarkan metode SAW ini, lampu yang disarankan untuk digunakan adalah LED dengan nilai kriteria tertinggi 9,66, kemudian lampu TL dengan nilai kriteria 6,93. SAW

Kata Kunci : Biaya, Lampu, Keuntungan, Penerangan,

\section{PENDAHULUAN}

Penerangan pada saat ini, merupakan hal yang tidak bisa dipisahkan dalam kehidupan.Karena berbagai macam kegiatan tergantung kepada penerangan. Misalnya pada dunia pendidikan. Khususnya dalam penggunaan ruang praktek komputer. Pencahayaan yang dibutuhkan untuk setiap ruang, pastinya berbeda tergantung dari kegunaan ruang tersebut. Sehingga pemilihan lampu yang tepat untuk ruang ini sangat diperlukan. Umur lampu yang semakin lama tentunya akan menghasilkan cahaya yang semakin redup sehingga akan berpengaruh besar terhadap kesehatan

Manuscript received March 22, 2016. This work was supported in part Information Technology Department Politeknik Negeri Padang.

Fitria Nova was with Information Technology Department Politeknik Negeri Padang, Indonesia ( corresponding author provide email fitrinova85@gmail.com ) mata pengguna ruangan tersebut. Pada penelitian ini, penulis akan meneliti tentang penggunaan jenis lampu yang tepat di Laboratorium Teknologi Informasi Politenik Negeri Padang dengan menggunaka implementasi FMADM. Sehingga nantinya akan mengetahui lampu yang tepat berdasarkan kriteria benefit yaitu, luas ruangan dan umur lampu, serta dari kriteria cost nya yaitu biaya listrik dan total lampu.

\section{CAHAYA}

Cahaya merupakan suatu bentuk energi yang diradiasikan atau dipancarkan dari sebuah sumber dalam bentuk gelombang dan merupakan bagian dari keseluruhan kelompok gelombang-gelombang elektromagnet. Panjang gelombang adalah jarak antara puncak-puncak gelombang energi. Cahaya alam dari matahari atau lampu wolfram sering disebut cahaya putih dan terdiri dari campuran spektrum dari semua cahaya pelangi [3]

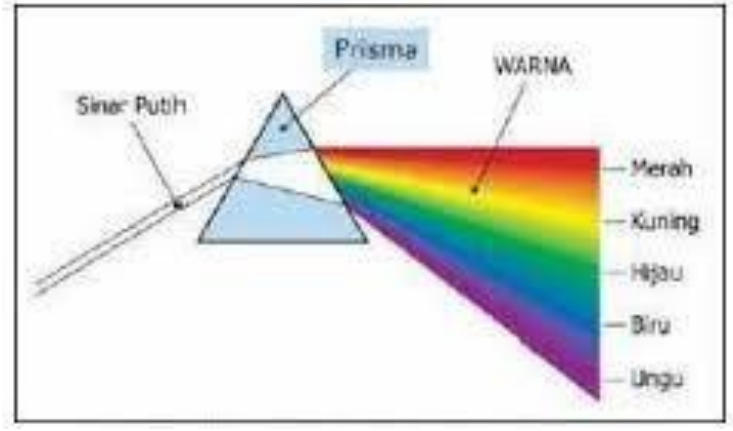

Gambar 1. Spektrum Warna

Dari gambar diatas dapat dilihat bahwa sinar- sinar cahaya yang meninggalkan prisma adalah dibelokkan. Merah dibelokkan paling kecil dan violet paling besar

\section{A. SATUAN DALAM PENERANGAN}

Satuan - satuan penting yang digunakan dalam teknik penerangan ialah :

Satuan untuk intensitas cahaya : kandela (cd) Satuan untuk flux cahaya : lumen (lm)

Satuan untuk intensitas penerangan

atau iluminasi : lux (lx)

Satuan untuk sudut ruang $\quad$ : steradian (sr) 


\section{B. INTENSITAS CAHAYA}

Kawat tahanan yang dialiri arus listrik akan berpijar dan memancarkan cahaya. Sumber cahaya yang demikian, misalnya lampu pijar, dinamakan pemancar suhu. Lampu pijar memancarkan energi cahaya ke semua jurusan. Tetapi energi radiasinya tidak merata. Jumlah energi radiasi yang dipencarkan sebagai cahaya dan dinyatakan sebagai cahaya ke suatu jurusan tertentudisebut intensitas cahaya dan dinyatakan dengan kandela (cd) [4]

\section{FLUX CAHAYA}

Suatu sumber cahaya yang memancar sama kuat ke setiap jurusan, dinamakan sumber cahaya seragam. Kalau intensitas cahayanya $1 \mathrm{~cd}$, melalui sudut ruang 1 sr akan mengalir flux cahaya $1 / \mathrm{m}$. Intensitas cahaya adalah flux cahaya per satuan sudut ruang yang dipancarkan ke suatu arah tertentu. Flux cahaya yang dipancarkan oleh suatu sumber cahaya ialah seluruh jumlah cahaya yang dipancarkan dalam satu detik. Kalau sumber cahayanya, misalnya lampu pijar, ditempatkan dalam reflektor, maka cahayanya akan diarahkan, tetapi jumlah atau flux cahayanya tetap. [4]

\section{INTENSITAS PENERANGAN}

Intensitas penerangan atau iluminasi di suatu bidang ialah flux cahaya yang jatuh pada $1 \mathrm{~m}^{2}$ dari bidang itu. Satuan untuk intensitas penerangan ialah flux (lx). 1 lux $=1$ lumen per $\mathrm{m}^{2}$

\section{E. LUMINANSI}

Luminansi ialah suatu ukuran untuk terang suatu benda. Luminansi yang terlalu besar akan menyilaukan mata, seperti misalnya sebuah lampu pijat tanpa armatur. Luminansi L suatu sumber cahaya atau suatu permukaan yang memantulkan cahaya ialah intensitas cahayanya dibagi dengan luas semu permukaan. Faktor refleksi suatu permukaan juga ikut menentukan luminansinya. Luas semu permukaan ialah luas proyeksi sumber cahaya pada suatu bidang rata yang tegak lurus pada arah pandang, jadi bukan luas permukaan seluruhnya.

\section{F. SISTEM PENERANGAN DAN ARMATUR}

Penyebaran cahaya dari suatu sumber cahaya tergantung pada konstruksi sumber cahaya itu sendiri dan pada konstruksi armatur yang digunakan. Konstruksi armaturnya antara lain ditentukan oleh :

a. Cara pemasangannya pada dinding atau langit langit

b. Cara pemasangan fiting atau fiting-fiting didalam armature

c. Perlindungan sumber cahayanya

d. Penyesuaian bentuknya dengan lingkungan

e. Penyebaran cahayanya

Sebagian besar dari cahaya yang ditangkap oleh mata, tidak datang langsung dari sumber cahaya, tetapi setelah dipantulkan oleh lingkungan. Karena besarnya luminansi sumber-sumber cahaya langsung dari sumber cahaya biasanya akan menyilaukan mata. Karena itu bahan-bahan armatur harus dipilih demikian rupa sehingga cahayanya terlindung dan cahayanya terbagi secara tepat. Berdasarkan pembagian flux cahayanya oleh sumber cahaya dan armatur yang digunakan, dapat dibedakan sistem-sistem penerangan dibawah ini :

Tabel 1. Sistem-sistem penerangan

\begin{tabular}{|} 
Tabel 1. Sistem-sistem penerangan \\
\hline Sistem Penerangan & $\begin{array}{l}\text { Langsung ke bidang } \\
\text { kerja }\end{array}$ \\
\hline a. Penerangan langsung & $90-100 \%$ \\
\hline $\begin{array}{c}\text { b. Terutama penerangan } \\
\text { langsung }\end{array}$ & $60-90 \%$ \\
\hline $\begin{array}{c}\text { c. Penerangan campuran atau } \\
\text { penerangan baur (difus) }\end{array}$ & $40-60 \%$ \\
\hline $\begin{array}{c}\text { d. Terutama penerangan } \\
\text { tak langsung }\end{array}$ & $10-40 \%$ \\
\hline e. Penerangan tak langsung & $0-10 \%$ \\
\hline
\end{tabular}

TABEL-TABEL PENERANGAN

Tabel 2. Tingkat pencahayaan minimum dan renderasi warna yang direkomendasikan

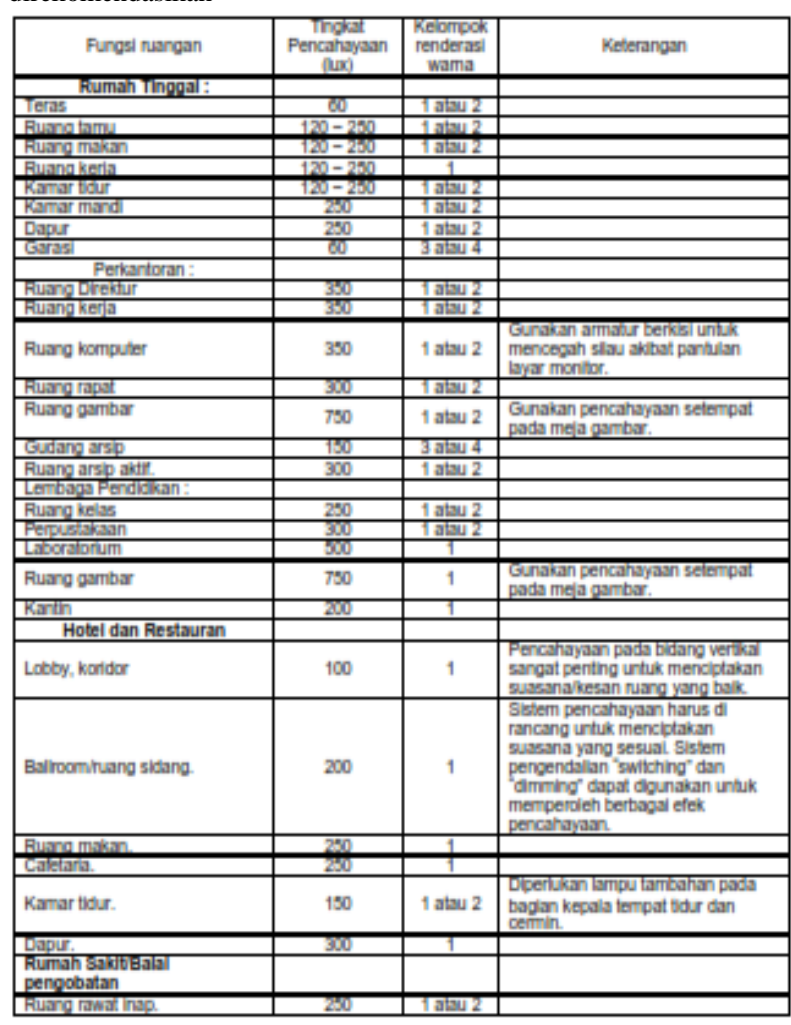

\section{G. JENIS - JENIS LAMPU}

1. Lampu TL

Lampu TL (tube lamp) atau disebut juga dengan lampu neon, yang tersusun dari tabung yang berisi sedikit gas mulia seperti argon atau neon, dan juga sedikit air raksa. Pada bagian dalam tabung tersebut diberi lapisan putih yang terbentuk dari bahan kimia, umumnya kalsium. Pada kedua ujung tabung terdapat filamen jika yang dipanaskan akan memancarkan elektron. Elektron ini mengalir lewat tabung ke ujung satunya. Selama melewati tabung, elektron akan bertumbukan dengan atom air raksa yang sudah menguap karena panas. Tumbukan 
ini akan menghasilkan energi yang kemudian diserap oleh atom air raksa. Energi terebut kemudian dipancarkan kembali lewat utraviolet. Lapisan putih pada tabung kemudian menyerap energi ultraviolet ini dan memancarkannya sebagian, sehingga terjadilan perpendaran. Inilah yang kita lihat sebagai cahaya lampu. Lampu ini lebih hemat dibandingkan dnegan lampu pijar, hal ini disebabkan karena panas yang diperlukan untuk memanaskan filamen agar memancarkan elektron tidak terlalu besar. Selain itu proses perpendarannya juga tidak memerlukan energi panas.

2. Lampu Hemat Energi (LHE)

Lampu hemat energi atau disebut dengan compact fluorescent adalah salah satu bentuk pengembang dari lampu fluorescent. Lampu ini terdiri dari ballast elektronik dan tabung gelas. Lampu hemat energi memiliki umur hidup hingga 8000 jam atau 10 kali lipat bila dibandingkan dengan lampu pijar. Bahkan, lampu hemat energi menggunakan energi $80 \%$ lebih sedikit dibanding lampu biasa.

3. Lampu LED (Light Emitting Diode)

Merupakan lampu terbaru yang memliki efisensi energi. Ketika lampu LED memancarkan cahaya yang nampak pada gelombang spektrum yang sangat sempit, mereka dapat memproduksi cahaya putih. Hal ini sesuai dengan kesatuan susunan merah - biru - hijau atau LED biru berlapis fosfor. Lampu LED bertahan dari 40.000 hingga 100.000 jam tergantung pada warna.

\section{H. ISTEM PENDUKUNG KEPUTUSAN}

SPK merupakan sebuah sistem berbasis komputer yang membantu dalam proses pengambilan keputusan. SPK sebagai sistem informasi berbasis komputer yangadaktif, interaktif, fleksibel, yang secara khusus dikembangkan untuk mendukung solusi dari permasalahan manajemen yang tidak terstruktur untuk meningkatkan kualitas pengambilan keputusan. Dengan demikian dapat ditarik satu definisi tentang SPK yaitu sebuah sistem berbasis komputer yang adaptif, fleksibel, dan interaktif yang digunakan untuk memecahkan masalah-masalah tidak terstruktur sehingga meningkatkan nilai keputusan yang diambil. [1]

\section{FUZZY}

Teori himpunan fuzzy merupakan perluasan dari teori himpunan klasik. Pada teori himpunan klasik (crisp), keberadaan suatu elemen pada suatu himpunan, A, hanya akan memiliki 2 kemungkinan keanggotaan, yaitu menjadi anggota A atau tidak menjadi anggota A. Suatu nilai yang menunjukkan seberapa besar tingkat keanggotaan suatu elemen (x) dalam suatu himpunan
(A), sering dikenal dengan nama nilai kenggotaan atau derajat keanggotaan dinotasikan dengan $\mu \mathrm{A}(\mathrm{x})$. Pada himpunan klasik, hanya ada 2 nilai keanggotaan, yaitu $\mu \mathrm{A}(\mathrm{x})=1$ atau untuk $\mathrm{x}$ menjadi anggota $\mathrm{A} ; \operatorname{dan} \mu \mathrm{A}(\mathrm{x})=$ 0 untuk $\mathrm{x}$ bukan anggota dari A.[2]

\section{J. MADM (Multi Attribut Decission Making)}

Algoritma MADM adalah :

1. Memberikan nilai setiap alternatif $\left(\mathrm{A}_{i}\right)$ pada setiap kriteria $\left(\mathrm{C}_{\mathrm{j}}\right)$ yang sudah ditentukan, dimana nilai tersebut diperoleh berdasarkan nilai crips; $\mathrm{i}=1,2, \ldots \mathrm{m}$ dan $\mathrm{j}=1,2, . . \mathrm{n}$.

2. Memberikan nilai bobot (W) yang juga didapatkan berdasarkan nilai crips.

3. Melakukan normalisasi matriks dengan cara menghitung nilai rating kinerja ternormalisasi ( $\mathrm{rij}_{\mathrm{j}}$ dari alternatif $\mathrm{A}_{\mathrm{i}}$ pada atribut $\mathrm{C}_{\mathrm{j}}$ berdasarkan persamaan yang disesuaikan dengan jenis atribut (atribut keuntungan/benefit $=$ MAKSIMUM atau atribut biaya $/ \operatorname{cost}=$ MINIMUM). Apabila berupa atribut keuntungan maka nilai crisp MAX (MAX Xij) dari tiap kolom, sedangkan untuk atribut biaya, nilai crisp MIN (MIN $X_{i j}$ ) dari tiap kolom atribut dibagi dengan nilai crisp ( $\left.\mathrm{X}_{\mathrm{ij}}\right)$ setiap kolom.

4. Melakukan proses perankingan dengan cara mengalikan matriks ternormalisasi (R) dengan nilai bobot $(\mathrm{W})$.

5. Menentukan nilai preferensi untuk setiap alternatif $\left(\mathrm{V}_{\mathrm{i}}\right)$ dengan cara menjumlahkan hasil kali antara matriks ternormalisasi (R) dengan nilai bobot (W). Nilai $\mathrm{V}_{\mathrm{i}}$ yang lebih besar mengindikasikan bahwa alternatif $\mathrm{Ai}_{\mathrm{i}}$ lebih terpilih.

\section{METODE SAW}

Metode SAW sering juga dikenal dengan istilah metode penjumlahan terbobot. Konsep dasar metodeSAW adalah mencari penjumlahan terbobot dari rating kinerja pada setiap alternatif pada semua atribut. Metode SAW membutuhkan proses normalisasi matriks keputuan (X) ke suatu skala yang dapat diperbandingkan dengan semua rating alternatif yang ada.

$r_{i j}=\left\{\begin{array}{c}\frac{x_{i j}}{\max _{i} x_{i j}} j i k a j \text { adalah atribut keuntungan (benefit) } \\ \frac{\min _{i j} x_{i j}}{x_{i j}} j i k a j \text { adalah atribut biaya (cost) }\end{array}\right.$.

Dimana $\mathrm{rij}_{\mathrm{ij}}$ adalah rating kinerja ternormalisasi dari alternatif $A_{i}$ pada atribut $C_{j} ; i=1,2, \ldots, m$ dan $j=1,2, . ., n$. Nilai preferensi untuk setiap alternatif $(\mathrm{Vi})$ diberikan sebagai :

$$
V_{i}=\sum^{n} \quad w_{j} r_{i j}
$$

Nilai Vi yang lebih besar mengindifikasikan bahwa alternatif Ai lebih terpilih. 


\section{HASIL DAN PEMBAHASAN}

Jumlah lampu dalam instalasi penerangan memegang peranan penting, kriteria yang ditetapkan dalam jurnal ini adalah :

$\mathrm{C}_{1}=$ Luas ruangan

$\mathrm{C}_{2}=$ Biaya listrik

$\mathrm{C}_{3}=$ Total lampu

$\mathrm{C}_{4}=$ Umur lampu

Kriteria luas ruangan dan umur lampu merupakan atribut bertipe benefit, sedangkan kriteria biaya listrik dan total lampu merupakan atribut cost.

Alternatif yang digunakan dalam penelitian ini adalah pijar, HLE, TL dan LED. Pencarian alternatif ini lampu ini dilakukan dengan metode SAW. Proses pada penelitian ini dimulai dengan membaca nilai atribut setiap kriteria untuk semua alternatif, dan membaca bobot dari setiap atribut. Proses diawali dengan membuat tabel rating kecocokan tiap alternatif dan tiap kriteria (Tabel 1). Nilai dari rating kecocokan ini merupakan penilaian subjective dari pembuat keputusan. Tabel 1. Nilai Rating Kecocokan

\begin{tabular}{|l|l|l|l||}
\hline \multirow{2}{*}{ Alternatif } & \multicolumn{3}{|c||}{ Kriteria } \\
\cline { 2 - 4 } & $\mathrm{C}_{1}$ & $\mathrm{C}_{2}$ & $\mathrm{C}_{3}$ \\
\hline pijar & 0,9 & 1,0 & 0,3 \\
\hline TL & 0,9 & 0,3 & 0,2 \\
\hline HLE & 0,9 & 0,3 & 0,5 \\
\hline LED & 0,9 & 0,1 & 0,9 \\
\hline Max & 0,9 & 1,0 & 0,9 \\
\hline Min & 0,9 & 0,1 & 0,2 \\
\hline
\end{tabular}

Setelah itu melakukan normalisasi terhadap tabel rating kecocokan kedalam bentuk yang dapat diperbandingkan ke semua rating alternatif dengan menggunakan persamaan 1 .

Tabel 2. Normalisas

\begin{tabular}{|l|r|r|r|r|}
\hline \multirow{4}{*}{ Alternatif } & \multicolumn{4}{|c|}{ Kriteria } \\
\cline { 2 - 5 } & $\begin{array}{c}\text { Luas } \\
\text { Ruan } \\
\text { gan } \\
\text { (B) }\end{array}$ & $\begin{array}{c}\text { Biaya } \\
\text { Listrik } \\
(\mathrm{C})\end{array}$ & $\begin{array}{c}\text { Total } \\
\text { Biaya } \\
\text { Lampu } \\
\text { (C) }\end{array}$ & $\begin{array}{c}\text { Umur } \\
\text { Lampu } \\
(\mathrm{B})\end{array}$ \\
\hline Pijar & 1,0 & 0,1 & 0,7 & 0,1 \\
\hline TL & 1,0 & 0,3 & 1,0 & 0,2 \\
\hline HLE & 1,0 & 0,3 & 0,4 & 0,3 \\
\hline LED & 1,0 & 1,0 & 0,2 & 1,0 \\
\hline
\end{tabular}

Sebuah atribut dinyatakan sebagai atribut bertipe keuntungan (benefit) adalah jika semakin tinggi nilai yang diberikan pada atribut tersebut maka alternatif pilihan tersebut semakin besar berpeluang mencapai peringkat rangking yang lebih tinggi. Sebaliknya atribut dinyatakan sebagai atribut bertipe biaya (cost) adalah jika semakin tinggi nilai yang diberikan pada atribut tersebut maka alternatif pilihan tersebut semakin kecil berpeluang mencapai peringkat rangking tinggi.

Nilai bobot (W) merupakan nilai yang diberikan oleh pengambil keputusan yang bersifat subjektif. Pada kasus ini nilai $\mathrm{W}$ yang diberikan adalah 2,4,3,3 yang berarti tingkat kepentingan untuk $\mathrm{C}_{1}$ adalah 2, $\mathrm{C}_{2}$ adalah 4, $\mathrm{C}_{3}$ adalah 3, $\mathrm{C} 4$ adalah 3.

Tahapan berikutnya adalah melakukan pengalian bobot dengan nilai yang telah ternormalisasi. Sehingga diperoleh tabel 3 .

Tabel 3. Perkalian bobot dengan yang telah dinormalisasi

\begin{tabular}{|l|r|r|r|r|r|}
\hline pijar & 2 & 0,4 & 2 & 0,3 & $\mathbf{4 , 7}$ \\
\hline TL & 2 & 1,33 & 3 & 0,6 & $\mathbf{6 , 9 3}$ \\
\hline HLE & 2 & 1,33 & 1,2 & 0,9 & $\mathbf{5 , 4 3}$ \\
\hline LED & 2 & 4 & 0,66 & 3 & $\mathbf{9 , 6 6}$ \\
\hline
\end{tabular}

Hasil perkalian data ternormalisasi dengan bobot kemudian dijumlahkan untuk setiap atribut per alternatif yang ada menghasilkan Nilai Alternatif. Nilai alternatif terbesar menunjukkan alternatif yang terbaik. Dari Tabel 3 dapat dilihat bahwa hasil tertinggi diperoleh oleh LED sebesar 9,66, yang artinya LED merupakan alternatif terbaik .

\section{SIMPULAN DAN SARAN}

\section{A. SIMPULAN}

1. Metode Simple Additive Weighting (SAW) dapat digunakan dalam pemilihan lampu sebagai penerangan pada labor Teknologi Informasi.

2. Metode SAW ini, memungkinkan banyak kriteria, sehingga pemilihan keputusan menjadi lebih baik.

3. Berdasarkan metode SAW ini, pemilihan alternatif terbaik adalah lampu LED dengan nilai kriteria 9,66 kemudian lampu TL dengan nilai kriteria 6,93.

B. SARAN

Pada penelitian ini, krtiteria yang dipergunakan hanya sebatas luas ruangan, biaya listrik, total biaya serta umur lampu. Untuk penelitian selanjutnya bias menambahkan kriteria yang lain sehingga menghasilkan alternatif yang lebih baik.

\section{DAFTAR PUSTAKA}

[1] Khoirudin, Akhmad Arwan. (2008). SNATI Sistem Pendukung Keputusan Penentuan Kelayakan Calon Rintisan Sekolah Bertaraf Internasional Dengan Metode Fuzzy Associative Memory. Jurusan Tekni Informatika, Fakultas Teknologi Industri, Universitas Islam Indonesia.

[2] Kusumadewi, dkk., (2006), Fuzzy Multi Attribute Decision Making, GrahaIlmu, Yogyakarta.

[3] Neidle, Michael. (1987). Teknologi Instalasi Listrik Edisi Ketiga. Erlangga. Jakarta.

[4] Setiawan E. Ir. D. Van Harten. (1995). Instalasi Listrik Arus Kuat 2. Bina Cipta. Bandung. 